\title{
Study of p53 expression in premalignant squamous epithelial lesions of cervix
}

\author{
Divya B. ${ }^{1}$, Ashwini Nayak U. ${ }^{1 *}$, Sridhar Honnappa ${ }^{2}$
}

\begin{abstract}
${ }^{1}$ Department of Obstetrics and Gynecology, ${ }^{2}$ Department of Pathology, M. S. Ramaiah Medical College, Bengaluru, Karnataka, India
\end{abstract}

Received: 21 June 2017

Accepted: 27 June 2017

\section{*Correspondence:}

Dr. Ashwini Nayak U.,

E-mail: ashwininayaku@gmail.com

Copyright: () the author(s), publisher and licensee Medip Academy. This is an open-access article distributed under the terms of the Creative Commons Attribution Non-Commercial License, which permits unrestricted non-commercial use, distribution, and reproduction in any medium, provided the original work is properly cited.

\section{ABSTRACT}

Background: Every year in India, 1,22,844 women are diagnosed with cervical cancer and 67,477 die from the disease. This study was done with the aim of studying the expression of p53 in pre-malignant squamous epithelial lesions of cervix.

Methods: Patients coming to our institution who are undergoing biopsy for abnormal cytology/colposcopy were included in the study. Total of 39 patients were studied. Immunohistochemistry was used to study the p53 expression in cervical intra-epithelial lesions.

Results: Out of 39 patients studied, p53 positivity was found in CIN 1 in $38.5 \%$ cases, CIN 2 and CIN 3 in $80.75 \%$.

Conclusions: The present study has showed that p53 expression increased with increasing severity of Cervical intraepithelial neoplasia (CIN) and this fact can be used in clinical practice to identify those patients who require more surveillance.

Keywords: Cervical intraepithelial neoplasia, Immunohistochemistry, p53

\section{INTRODUCTION}

Every year in India, 1,22,844 women are diagnosed with cervical cancer and 67,477 die from the disease. ${ }^{1}$ Cervical cancer is the most common cause of death in cancer in the developing countries and hence a lot of emphasis is being placed on developing methods for early detection. Among the cancers attributable to high-risk HPV infection, cervical cancer has received the most attention and HPV-16, $-18,-31,-45$ accounts for more than $90 \%$ of cervical carcinomas. ${ }^{2}$

There are eight ORFs (open reading frames) transcribed from one DNA strand in the genome of HPV types. The ORF's are classified into three parts: the early (E) region that encodes proteins (E1-E7) necessary for viral replication, the late $(\mathrm{L})$ region that encodes the structural proteins (L1-L2) and the long control region (LCR), a largely non-coding part. When transfected, the E6 and E7 genes of the high-risk HPV types immortalize human keratinocytes, in contrast to low risk strains. ${ }^{3}$ The E6 protein binds p53 and abrogates its tumour suppressive and transcriptional properties by promoting ubiquitination of p53 and its subsequent proteolysis through interaction with the E6AP ubiquitin-protein ligase. ${ }^{4,5}$

p53 is a regulator of apoptosis and it can inhibit cell proliferation. In cervical cancer cells, these properties of p53 is destroyed leading to cell proliferation. Thus, p53 tumor suppressor gene expression may be used as a useful marker to prognosticate the outcome of the patients. Immunohistochemically, it is difficult to detect wild p53 protein expression, but mutated protein-present 
intranuclear can be easily detected by immunoperoxidase method. ${ }^{6}$ Therefore, this study was done to see the immune-histochemical expressions of p53 in different grades of CIN lesions so that one can select a specific set of patients who express p53 who need more surveillance and hence can help averting unnecessary radical procedures for all CIN lesions.

\section{METHODS}

Patients coming to the institution who underwent biopsy for abnormal cytology/colposcopy were included in the study. Out of 39 patients studied-13 of CIN 1, 13 of CIN 2, 13 of CIN 3. The demographic data and the history was obtained regarding name, age, education level, occupation, address, chief complaints, personal history and any other associated complaints. Information was also collected regarding the reproductive history such as the parity, number of abortions and the contraceptive history. Any history of multiple sexual partners was also elicited. Any other relevant medical and family history was noted. Consent from the patient was taken for local examination and biopsy was taken from the suspected area after application of 5\% acid or Lugol's iodine. Hysterectomy specimens were also considered for the study.

Biopsy was processed and stained with Hematoxylin and Eosin staining. The sections were examined for dysplasia and for p53 expression. In the lab, specimen was processed for routine paraffin embedded block preparation. From each block, 3-4 micron thick multiple sections were cut. One section was stained with hematoxylin and eosin for observed histological grading and rest of the sections were stained with immunostaining of p53 using the Horseradish peroxidase method. The positivity was considered if more than $10 \%$ of nuclei are stained. The polymer based IHC kit of PathnSitu RTU was used. The primary study outcome was CIN grade, categorized as: CIN I, CIN II and CIN III.

\section{Statistical analysis}

All the quantitative variables such as age was analysed and described in terms of mean and standard deviation. All qualitative variables were expressed in terms of percentages. The data were analysed and processed by the SPSS program, version 20. For statistical analysis both the non-parametric tests of pearson's Chi-square X2 and Fishers exact test were used. $\mathrm{p}<0.05$ values were considered statistically significant.

\section{RESULTS}

In the present study, out of 39 patients studied-13 of CIN 1, 13 of CIN 2, 13 of CIN 3. The age distribution of the patients ranged from 25 years to 70 years. Mean age was $46.23 \pm 10.42$ years. The age of the patients with CIN 1 lesions ranged from 25 to 69 years with the mean age being $46.23 \pm 13.26$ years. The age of the patients with
CIN2 and CIN3 lesions ranged from 29 to 70 years with the mean age being $46.23 \pm 8.99$ years (Table 1 ). Table 1: Distribution of CIN lesions according to
mean age.

\begin{tabular}{ll} 
Different lesions & Mean age \pm standard deviation \\
CIN1 & $46.23 \pm 13.26$ \\
\hline CIN2and3 & $46.23 \pm 8.99$ \\
\hline
\end{tabular}

Out of the 39 patients, $12.8 \%(\mathrm{~N}=5)$ were belonging to urban region while the majority $87.17 \% \quad(\mathrm{~N}=34)$ were from the rural area. Among the 13 CIN 1 patients, $76.92 \%(\mathrm{~N}=10)$, CIN 2 patients-84.61\% $(\mathrm{N}=11)$ and CIN3 $100 \%$ were from the rural area. out of the 39 patients, $33.3 \%$ of the patients were uneducated, $58.9 \%$ had studied upto primary school and only $7.8 \%$ had studied upto secondary education. $87.17 \%(\mathrm{~N}=34)$ of the patients were house wives while the rest were working. Out of the 13 patients with CIN 1 15.38\%, CIN 2-7.69\% and CIN3-15.38\% belonged to the working class. Parity of the patients ranged from para1 to para $6.69 .23 \%$ of the CIN 1 patients, $76.9 \%$ of CIN 2 and $100 \%$ of CIN 3 had a parity index of $\geq 2$. Age at which first child was born from 15 to 21 years while the age of the first child of the patients ranged from 15 to 25 years. Out of the 39 patients with CIN lesions, $66.66 \%$ of the lesions expressed p53. Out of CIN $138.46 \%$ of the lesions expressed p53, 80.7\% of the CIN 2 and 3 lesions expressed (Table 2).

Table 2: Distribution of CIN lesions according to p53 expression.

\begin{tabular}{|ll|}
\hline Different lesions & P53 expression \\
\hline CIN 1 & $38.46 \%$ \\
\hline CIN 2 and CIN 3 & $80.7 \%$ \\
\hline
\end{tabular}

\section{DISCUSSION}

Cervical cancer has a long latent phase during which it can be detected as identifiable and treatable premalignant lesions which precede the invasive disease and the benefit of conducting screening for carcinoma cervix exceeds the cost involved. ${ }^{7}$ Out of the 39 patients, the mean age was $46.23 \pm 13.26$ years. This is similar to the study by Astrid et al (45 years). ${ }^{8}$ Patients who started sexual activity before 20 years of age were found to have LSIL and HSIL on cytology. ${ }^{9,10}$ This is similar to our study in which majority of the patients had their marriage before 21 years. Majority $87.17 \%$ of the patients in our study were from the rural area, but this is in contrast to the China Cancer Registration Annual Report 2004, in which 43 cancer registries were included, the incidence of cervical cancer was 5.3 per 100,000 in urban and 4.9 per 100,000 in rural areas. ${ }^{11}$ Similar to the present study, the incidence of high-grade lesion for cervical cancer was found to be high among the rural population and they were susceptible to develop the cancer as shown in the study by Parimala A et al. ${ }^{12}$ High education level (college 
and above compared with junior middle school or lower) was found to be protective for HSIL ( $\mathrm{aOR}=0.79,95 \%$ CI: $0.37-0.90)$ in the study by Lixin Tao et al. ${ }^{13} 60 \%$ of the women were house wives in the study done by Niveditha VS et al while in the present study, $87.7 \%$ were house wives. ${ }^{14}$ Women with parity of 3 and more are likely to have more precancerous lesions in the study by Swapnali Patil et al and this is similar to our study in which $100 \%$ of CIN 3 had a parity index of $\geq 2 .{ }^{15}$ In the study done by Shukla et al, p53 immunoreactivity was found to be progressive from CIN 1 to CIN 3 [CIN 1 $(22.2 \%)$, CIN $2(50 \%)$, CIN $3(100 \%)]$ with $\mathrm{p}$ value of $0.10 .{ }^{16}$ In the present study, out of CIN $138.46 \%$ of the lesions expressed p53, 80.7\% of the CIN 2 and 3 lesions expressed p53.

\section{CONCLUSION}

Studies have shown p53 expression increases with increasing severity of CIN and this fact can be used in clinical practice to identify those patients who require more surveillance. Studies have shown that p53 can be used as a prognostic factor for the aggressive behaviour of the tumor. Hence p53 protein expression in cervical epithelium may be a useful marker contributing information complementary to morphology and prognosis.

\section{Funding: No funding sources}

Conflict of interest: None declared

Ethical approval: The study was approved by the Institutional Ethics Committee

\section{REFERENCES}

1. ICO Information Centre on HPV and cancer (Summary Report 2014-08-22). Human Papillomavirus and Related Diseases in India. 2014

2. Muñoz N1, Bosch FX, de Sanjosé S, Herrero R, Castellsagué $\mathrm{X}$, Shah KV et al. Epidemiologic classification of human papillomavirus types associated with cervical cancer. $N$ Engl J Med. 2003;348(6):518-27.

3. Wan F, Miao X, Quraishi I, Kennedy V, Creek KE, Pirisi L. Gene expression changes during HPVmediated carcinogenesis: a comparison between an in vitro cell model and cervical cancer. Int J Cancer. 2008;123(1):32-40.

4. Werness BA, Levine AJ, Howley PM. Association of human papillomavirus types 16 and 18 E6 proteins with p53. Science. 1990;248(4951):76-9.

5. Scheffner M, Werness BA, Huibregtse JM, Levine AJ, Howley PM. The E6 oncoprotein encoded by human papillomavirus types 16 and 18 promotes the degradation of p53. Cell. 1990;63(6):1129-36.

6. Lool ML, Dali AZ, Ali SA, Ngah WZ, Yusof YA.. Expression of p53, bcl2 and Ki-67 in cervical intraepithelial neoplasia and invasive squamous cell carcinoma of the uterine cervix. Anal Quant Cytol Histol. 2008;30(2):63-70.

7. Kerkar RA, Kulkarni YV. Screening for cervical cancer: An overview. J Obstet Gynecol India. 2006;56:115-22.

8. Baalbergen A, Ewing-Graham PC, Eijkemans MJ, Helmerhorst TJ. Prognosis of adenocarcinoma of the uterine cervix: p53 expression correlates with higher incidence of mortality. Int J Cancer. 2007;121:106110 .

9. Khattak ST, Khattak I, Naheed T, Akhtar S, Jamal T. Detection of abnormal cervical cytology by pap smears. Gomal J Med Sci. 2006;4:74-7.

10. Sherwani RK, Khan T, Akhtar K, Zeba A, Siddiqui FA, Rahman $\mathrm{K}$ et al. Conventional Pap smear and liquid based cytology for cervical cancer screening: a comparative study. J Cytol. 2007;24:167-72.

11. National Office for Cancer Prevention and Control. Chinese Cancer Annual Report 2004. Beijing: Publication House of Peking Union Medical College; 2008.

12. Parimala A, Sharma N, Srinivasan JK. Screening of cancer cervix: Pap smear in rural India. Int J Reprod Contracept Obstet Gynecol. 2017;5(7):2113-5.

13. Tao L, Han L, Li X, Gao Q, Pan L, Wu L, Luo Y, Wang W, Zheng Z, Guo X. Prevalence and risk factors for cervical neoplasia: a cervical cancer screening program in Beijing. BMC Public Health. 2014;14(1):1185.

14. Nivedhitha VS, Sankareswari R. Study of effectiveness of combined test Pap smear, visual inspection with acetic acid and Lugols iodine for mass screening of premalignant and malignant lesions of cervix. Int J Reprod Contracept Obstet Gynecol. 2017;5(3):725-9.

15. Patil S, Patil A, Solanke P. Cytological Screening for early Diagnosis of Cervical Intraepithelial Neoplasia (CIN) and early Carcinoma of Cervix. Int J Sci Res Publ. 2015;5:1-6.

16. Shukla S, Dass J, Pujani M. p53 and bcl2 expression in malignant and premalignant lesions of uterine cervix and their correlation with human papilloma virus 16 and 18. South Asian J Cancer. 2014;3(1):48.

Cite this article as: Divya B, Nayak UA, Honnappa S. Study of p53 expression in premalignant squamous epithelial lesions of cervix. Int J Reprod Contracept Obstet Gynecol 2017;6:3297-9. 